\title{
Comments
}

\section{The Zero Basis Dilemma in Nonqualifying Triangular Acquisitions}

In effectuating corporate acquisitions, triangular reorganizations have been recognized as an important alternative to direct exchange of an acquiring corporation's stock for the stock or assets of the corporation to be acquired. ${ }^{1}$ In the typical triangular reorganization the parent corporation $(P)$ transfers shares of its voting stock to a subsidiary $(S)$ - usually wholly owned by $P$-either as a capital contribution ${ }^{2}$ or in exchange for shares of $S$ 's own stock. $S$ subsequently transfers the $P$ shares to an unrelated "target" corporation $(T)$ in exchange for the stock or assets of $T$. If a triangular stock-for-stock or stock-for-assets acquisition meets the requirements of section $368(a)(1)(B)$ or 368(a) (1)(C) of the Internal Revenue Code, the parties do not recognize gain or loss on the transaction, ${ }^{3}$ and $S$ takes a carryover basis in $T$ 's assets or stock. ${ }^{4}$ Although triangular acquisitions are also possible through merger under section $368(a)(1)(A)$ as modified by sections $368(a)(2)(D)$ and $(a)(2)(E)$, these transactions do not raise the peculiar problems of basis determination that are present in acquisitions treated by section $368(\mathrm{a})(\mathrm{I})(\mathrm{B})$ and $(\mathrm{a})(\mathrm{I})(\mathrm{C})$-so-called $(\mathrm{B})$ and $(\mathrm{C})$ reorganizations.

If the transaction does not qualify as a (B) or (C) reorganization, ${ }^{5}$

1 The triangular reorganization offers several nontax advantages: avoiding risk of exposure of the parent corporation's business and assets to the liabilities of the acquired corporation; avoiding the necessity of stockholder action by the parent corporation (assuming that there is stock available to make the acquisition). See Shors, The Role of the Subsidiary in Corporate Reorganization, 18 DRAKE L. REv. 175 (1969); Walsh \& Gerard, Planning Possibilities in Using Parent's Stock in a Corporate Acquisition, 30 J. TAx. 168 (1969).

2 Treasury Regulation section 1.118-1 (1956) provides that voluntary payment of funds by a shareholder, where there is no increase in the outstanding shares of stock of the corporation, represents "an additional price paid for the shares of stock held by the individual shareholder." Section 1016(a) states that "[p]roper adjustment in respect of the property shall in all cases be made-(l) for expenditures . . properly chargeable to capital account ... ." INT. REv. CoDE of 1954 § 1016(a) [hereinafter cited as INT. REv. CODE]. Thus $P$ 's basis in its $S$ stock will be increased by the amount of its contribution.

3 See INr. REv. Code § 368(a)(1)(B), (a)(1)(C); Rev. Rul. 57-278, 1957-1 CuM. BuLx. 124.

4 INT. REv. CoDE $\$ 362$ (b).

5 Although "reorganization" has meaning independent of the Internal Revenue Code, 
however, $S$ recognizes gain or $\operatorname{loss}^{6}$ equal to the difference between the fair market value of the property received ( $T$ stock or assets) and its basis in the property it exchanged ( $P$ stock). ${ }^{7}$ The basis of the $P$ stock exchanged by $S$ is, therefore, a crucial determinant of the amount of gain or loss recognized. If $P$ later divests itself of $S$ in a taxable sale or exchange, it is also necessary to determine how the triangular transaction affects $P$ 's basis in the $S$ stock it holds.

The problem of determining the bases of the parent and subsidiary in each other's stock is not peculiar to attempted triangular reorganizations that fail to qualify for nonrecognition. It arises whenever the parent or the subsidiary disposes of the other's stock to one other than the issuer. There is substantial disagreement over how these bases should be computed. ${ }^{8}$ This comment analyzes the various interpreta-

as used in this comment the term stands for a transaction on which gain or loss would be recognized but for sections 354,361 , and 368 of the Code.

Failure to qualify may occur if, for example, (1) a prior spinoff prevents the subsidiary from acquiring "substantially all" of the target company's assets in an attempted subsidiary merger under section $368(\mathrm{a})(2)(\mathrm{D})$; (2) the consideration given by the acquiring corporation does not consist solely of voting stock in an attempted (B) reorganization; (3) what is exchanged for the assets in an attempted $(C)$ reorganization consists of more nonqualifying consideration ("boot") than is permitted by section $368(\mathrm{a})(2)(\mathrm{B})$; or (4) in an attempted (C) reorganization, the subsidiary acquires all the assets using its parent's stock, and the parent assumes some of the liabilities of the acquired corporation. Rev. Rul. 70-107, 1970-1 Cum. Bulz. 78.

- INT. REv. CODE § 1002.

7 Id. \$ 1001.

8 Commentators recognizing the problem of computing the basis of $P$ stock to $S$ include B. Bitrker \& J. Eustice, Federal Income TaXation of Corporations and Shareholders, chs. 3, 14 (3d ed. 1971, Súpp. 1973); Cornfeld, Intercorporate Transactions in Stock or Debt of an Affiliate, Including the Effect of Transactions with Non-Related Parties, N.Y.U. 30TH INST. ON FED. TAX. 1347 (1972); Ferguson \& Ginsburg, Triangular Reorganizations, 28 TAX L. REv. 159 (1973) [reprinted from U. So. CAL. 1972 TAX INST. 1]; Freling, Current Problems in Subsidiary Mergers and Other Triangular Reorganizations, N.Y.U. 29TH INST. on FEd. TAX. 347 (1971); Freling, Three-Party Reorganizations, TULANE 1973 TAX INST. 179; Landis, Contributions to Capital of Corporations, 24 TAX L. REv. 241 (1969); Levin, The New Subsidiary-Merger Statute and Other Current Tax Problems in Acquisitions, 47 TAXES 779 (1969); N.Y. State Bar Ass'n Comm. on Corporate Taxation, Sale or Exchange by a Subsidiary Corporation of Its Parent Corporation's Stock, 47 TAxes 146 (1969) [hereinafter cited as Committee on Corporate Taxation]; Sapienza, Tax Considerations in Corporate Reorganizations and Mergers, 60 Nw. U.L. Rev. 765 (1966); Stinson, Some Subchapter C Trouble Spots-After Two Years, 34 TAXEs 890 (1956); Stutsman, Triangular Mergers, 50 TAXEs 820 (1972).

For discussion of the problems of computing the basis of $S$ stock to the parent, see commentators cited supra; Barker et al., Current Techniques in Corporate Acquisitions, U So. CAL. 1970 TAX INsT. 317; Dubin, Unscrambling an Acquisition, 49 TAxzs 849 (1971); Evall et al., Tax and Practical Considerations in the Negotiation for the Purchase/Sale of a Going Business: A Panel Discussion, N.Y.U. 30TH INST. ON FED. TAX. 893 (1972); Lowenstein, "A" Reorganizations: Technical Requirements for Compliance Under the New Law, $30 \mathrm{~J}$. TAX. 169 (1969); Marold, Sale of a Subsidiary; Intercorporate Dividends; Section 332; 
tions of the method for calculating the basis of the parent's stock in the hands of the subsidiary and the basis of the subsidiary's stock held by the parent under the present Code and regulations and describes an alternative approach. Focusing on nonqualifying triangular acquisitions involving a parent, its wholly-owned subsidiary, ${ }^{9}$ and a target corporation presents the basis problem in its clearest form.

\section{Basis of the Parent's Stock to the Subsidiary}

The subsidiary's basis in the $P$ stock it holds can be set at either zero or at the cost of the $P$ stock. The Code gives no explicit support to either alternative, and its draftsmen apparently never anticipated that the problem would arise..$^{10}$ Although a zero basis is semantically consistent with the relevant portions of the Code, a careful reading of the provisions and an analysis of their underlying policies indicate that the "cost or fair market value" approach is more appropriate.

\section{A. The Zero Basis Theory}

It has been suggested ${ }^{11}$ that the subsidiary takes a carryover basis in the $P$ stock it receives, because the transfer of the stock is invariably characterized as one of several transactions covered by Code provisions that specify such a basis: contributions to capital under section $118 ; ;^{12}$ transfers of stock to a controlled corporation under section $351 ;^{13}$ or acquisitions of property in connection with a reorganization. ${ }^{14}$ If the

Fairfield Steamship Company Rule, N.Y.U. 15TH INST. ON Fed. Tax. 711 (1956); Odell, Terminating Corporate Marriages: Divorce or Annulment, N.Y.U. 30TH INST. ON FED. TAX. 961 (1972); Points to Remember, 23 ABA TAX LAWYER 195 (1969).

9 This analysis assumes that the subsidiary is wholly-owned. Otherwise problems arise with respect to minority shareholders. Discussion of those problems is beyond the scope of this comment.

10 Reference to this particular basis problem is conspicuously absent from the committee reports accompanying the 1954 Internal Revenue Code. See H.R. REP. No. 1337, 83d Cong., 2d Sess. (1954); S. Rep. No. 1622, 83d Cong., 2d Sess. (1954); Conf. Rep. No. 2543, 83d Cong., 2d Sess. (1954).

11 See Ferguson \& Ginsburg, supra note 8, at 206 and n.102.

12 INT. REv. CODE $\S 118$ provides: "(a) . . . In the case of a corporation, gross income does not include any contribution to the capital of the taxpayer. (b) ... For basis of property acquired by a corporation through a contribution to its capital, see section 362."

13 "For the basis of stock, securities, or property received in an exchange to which this section applies, see [section] ...362." Id. § 351(e)(2).

14 Id. \& 362(b). Treasury Regulation section 1.1032-1(d) (1956) states: "For basis of property acquired by a corporation in connection with a transaction to which section 351 applies or in connection with a reorganization, see section 362. For basis of property acquired by a corporation in a transaction to which section 1032 applies but which does not qualify under any other nonrecognition provision, see section 1012."

It seems unlikely that a Treasury regulation could effectively modify a federal statute, 
parent corporation's basis in its own stock is zero, then the subsidiary's carryover basis is also zero. ${ }^{15}$

1. Characterizations of the Transaction. If $P$ transfers shares of its own stock to $S$ without receiving $S$ shares in return, the transaction is a contribution to capital governed by section $118 .{ }^{16}$ That provision states that the basis of property acquired as a contribution to capital is determined under section 362 , which provides that the "basis shall be the same as it would be in the hands of the transferor, increased in the amount of gain recognized to the transferor on such transfer."17

especially since Congress apparently has not granted explicit authority for the Service to do so. The Code provides, however, that cross references-such as those in sections 1032(b) and $118(\mathrm{~b})$ to the basis provisions of section 362-in which "the word 'see' is used, are made only for convenience, and shall be given no legal effect." INT. REv. CODE § 7806(a) (emphasis added). Nonetheless, explicit mention of the applicability of the carryover basis rule to section 1032 was made in H.R. REP. No. 1337, supra note 10, at 427 and S. REP. No. 1622, supra note 10, at A269.

15 See, e.g., Barnet S. Milman, Inc. v. Commissioner, 114 F.2d 95 (2d Cir. 1940).

16 INT. REv. CODE § 118; Treas. Reg. § 1.118-1 (1956). Whether $P$ stock is "property" is relevant in determining whether section 118 technically applies. Although the term "property" does not appear in section 118, Treasury Regulation section 1.118-1 repeatedly refers to a "contribution of money or property." See text and notes at notes 20-21 infra.

If a constructive issuance of stock from $S$ to $P$ is inferred in this transaction, however, section 118 is technically inapplicable. Revenue Ruling 64-155, 1964-1 Cum. BuLx. 138, indicates that a contribution to the capital of a wholly-owned corporation should be viewed as involving a "constructive" issuance of additional shares of stock in exchange for the contributed property. Thus section 351 or section 1032, rather than section 118 , would be applicable to $S$ on the "drop down." See note 30 infra.

This "constructive exchange" theory was rejected, however, in Abegg v. Commissioner, 429 F.2d 1209 (2d Cir. 1970), when the court of appeals (as did the Tax Court below in Werner Abegg, 50 T.C. 145 (1968)) expressly refused to follow Revenue Ruling 64-155. Abegg, which concerned a contribution to capital of a controlled foreign corporation governed by section 367 , distinguished King v. United States, 79 F.2d 453 (4th Cir. 1935), and Commissioner v. Morgan, 288 F.2d 676 (3d Cir.), cert. denied, 368 U.S. 836 (1961), cited as authorities in the Ruling. See Committee on Corporate Taxation, supra note 8, at 147 n.3; Ferguson \& Ginsburg, supra note 8, at 206 n.103. After Abegg was decided, section 367 was amended by Public Law No. 91-681 (Jan. 12, 1971), which, inter alia, adopted the position of the Internal Revenue Service on contributions of property to controlled foreign corporations as expressed in Revenue Ruling 64-155. Because section 367(d) now states that such a contribution to capital "[shall] be treated as an exchange of such property for stock of the foreign corporation equal in value to the fair market value of the property transferred," it is doubtful that the judicial rejection of the constructive stock issuance theory in Abegg renders section 1032 clearly inapplicable under the "drop down" method. B. BITIKER \& J. EUSTICE, supra note 8 , 7.23, at 7-52 n.95, rightly interpret $A b e g g$ as being overruled by the 1971 amendment to section 367 . In fact, a congressional committee report referred to a "recent court case," undoubtedly $A b e g g$, which would effectively be overruled by the revised section 367 (d). H.R. REP. No. 1762, 91st Cong., 2d Sess. 4 (1970). See also Dreier, Meeting the Problem of the Section 367 Ruling, N.Y.U. 30TH INST. ON FED. TAX. 1073, 1080 (1972); Note, 36 J. TAX. 39 (1972).

17 INT. REV. CODE \& 362(a)(2). 
Because $P$ recognizes no gain or loss on this transfer, ${ }^{18} S$ assumes $P$ 's basis for the latter's stock.

If $P$ 's transfer of its shares to $S$ is accompanied by receipt of $S$ shares in return, it is considered a transfer of property to a controlled corporation governed by section 351. $S$ takes a carryover basis in the $P$ stock. ${ }^{19}$ Section 351(a) provides: "No gain or loss shall be recognized if property is transferred to a corporation ... by one or more persons solely in exchange for stock or securities in such corporation and immediately after the exchange such person or persons are in control (as defined in section 368(c)) of the corporation. ..." The term "property" in section 351 (a) is not defined by the Code, ${ }^{20}$ and might not include the $P$ stock.21 Two prominent commentators have argued, however, that section 351 applies to an exchange by the parent of its stock for stock of its controlled subsidiary, despite the absence of directly apposite rulings. ${ }^{22}$

$18 P$ 's contribution to the capital of $S$ is not a "sale or exchange" of property, id. $\S$ 1002 , and therefore $P$ recognizes no gain or loss.

$19 I d$. $\$ 362(a)(1)$. Even if $S$ does not give $P$ any shares in the exchange for the $P$ stock, $S$ may be viewed as constructively issuing shares to $P$. See note 16 supra.

20 The definition appearing in section 317(a) applies only to Part I of Subchapter C, sections 301-18. If the section 317 (a) definition were held applicable, then section 351 apparently would not prevent recognition.

21 There are no compelling policy reasons for either inclusion or exclusion of $P$ stock under the term "property." A newly organized corporation does not usually need shares of its parent's stock for working capital or for operating assets. On the other hand, triangular reorganizations are recognized as legitimate business devices, see note 1 supra, and the exchange in question is not a sham and does not lack business purpose. "Property" might include treasury stock, yet exclude authorized but unissued stock. Unlike unissued stock, treasury stock is generally capable of sale at a price below par value. See, e.g., InI. Rev. Stat. ch. 32 \& 157.18 (1971); ABA-ALI MOdel Bus. CoRp. Act \& 18 (2d ed. 1971). Use of treasury stock may prevent other shareholders of $P$ from exercising their pre-emptive rights to preserve their voting power. These two advantages seem insufficient, however, to grant treasury shares superior (or sole) status as "property." Accord, Rich, Tax Status of Transactions by a Corporation in its Own Capital Stock, N.Y.U. 8TH INST. ON FED. TAX. 770, 773 (1949). Contra, 3 J. Mertens, Law of Federal Income Taxation, \& 20.47 (1972 rev.) (newly issued stock apparently not "property" as used in section 351).

22 B. BrTtKer \& J. Eustice, supra note 8, $\uparrow$ 3.03, at 3-10. Cornfeld, supra note 8, at 1358, also believes this transfer obtains tax-free status under section 351. Cf. Rev. Rul. 73-246, 1973 INT. REv. BuLc. No. 23, at 8 , in which shareholder $B$, already the owner of all the shares of both $X$ and $Z$ corporations, transferred all of $Z$ 's shares to $X$ in exchange for additional shares of $X$; it was held that "no gain or loss [is] recognized" to $B$ under section 351(a). If $S$ is not wholly owned by $P$, section 351 cannot apply unless $S$ shares are actually transferred to $P$. The "constructive exchange" approach, supra note 16, does not apply otherwise-and should not. If $P$ owns less than 100 percent of $S$ 's shares, an imputed exchange of $S$ stock would increase $P$ 's proportionate ownership of $S$, and thus reduce the proportionate holdings of $S$ 's other stockholders. When it would change the various shareholders' interests, a constructive exchange should not be imputed without a clear indication of their intent. 
If $P$ transfers shares of its own stock to $S$ "in connection with a reorganization," $S$ 's basis in the $P$ stock is determined by section $362 . .^{23}$ The scope of the phrase "in connection with a reorganization" is vague. ${ }^{24}$ In executing a triangular reorganization, $S$ may be transferring stock received from $P$ much earlier through an unrelated transaction. Thus it is not clear that, at the time of the original transfer of $P$ stock, $S$ acquired property ${ }^{25}$ "in connection with a reorganization," because in many cases no specific reorganization had yet been conceived. ${ }^{28}$ It has been suggested that the meaning of the phrase, which is somewhat looser than the requirement that an exchange be "in pursuance of a plan of reorganization," may embrace this first transfer of $P$ stock to $S .{ }^{27}$ Alternatively this exchange of stock could, by itself, technically qualify as a reorganization under section $368(\mathrm{a})(1)(\mathrm{B})$ if $S$ is a pre-existing corporation and is controlled by $P .{ }^{28}$

If the transfer of $P$ stock for $S$ stock is an actual or constructive ${ }^{29}$ exchange, section 1032 provides nonrecognition to $S .{ }^{30}$ Where section 1032 applies, and the transaction is also viewed as being "in connection

23 INr. REv. CoDE $\$$ 362(b). See note 14 supra.

24 See B. BIITKER \& J. EusTice, supra note 8, ๆ 14.33, at 14-84 n.143.

25 Moreover, like section 351, neither Treasury Regulation section 1.1032-1(d) (1956) nor section 1032 of the Code define "property." It is therefore not certain that "property" includes stock.

20 That $S$ received the $P$ stock several years earlier, however, is not determinative; the unity of steps in a reorganization is not dependent upon how closely they follow one another chronologically. See D.W. Douglas, 37 B.T.A. 1122 (1938) (five-year lapse does not disqualify a reorganization); Manning, "In Pursuance of the Plan of Reorganization": The Scope of the Reorganization Provisions of the Internal Revenue Code, 72 HARv. L. REv. 881, 915 (1959); Mintz \& Plumb, Step Transactions in Corporate Reorganizations, N.Y.U. 12TH INST. ON Fed. TAX. 247, 249 (1954).

27 B. BITTKER \& J. EUstice, supra note 8, ๆ 14.33, at 14-84 n.143.

28 As Bittker and Eustice appropriately comment on a similar situation, "Although the transaction literally qualifies as a Type B reorganization, even a casual student of the step-transaction doctrine . . w would refuse to insure such a device . . . B. BrTTKeR \& J. EusticE, supra note $8, \pi 14.13$, at 14-40. It has long been held (under the predecessor of section 351) that several transfers need not be effected simultaneously to be treated as one if the various transactions have been executed in pursuance of an antecedent arrangement. E.g., Portland Oil Co. v. Commissioner, 109 F.2d 479, 488 (1st Cir. 1940).

29 See note 16 supra.

30 "No gain or loss shall be recognized to a corporation on the receipt of money or other property in exchange for stock (including treasury stock) of such corporation." INT. Rev. CoDE § 1032(a). A constructive exchange might not fall within section 1032. It has been held that the motive or intent of the parties to the transaction is relevant in determining whether the corporate recipient enjoys nonrecognition under section 1032. Federal Employees' Distrib. Co. v. Commissioner, 322 F.2d 891 (9th Cir. 1963); Affiliated Gov't Employees' Distrib. Co. v. Commissioner, 322 F.2d 872, 877 (9th Cir. 1963). But see Federal Employees' Distrib. Co. v. Franchise Tax Bd., 260 Cal. App. 2d 937, 945, 67 Cal. Rptr. 696,701 (1968). Thus a constructive exchange may lack the intent necessary for section 1032 to apply. See note 16 supra. 
with a reorganization" or as a transfer to a controlled corporation under section $351,31 S$ takes a carryover basis in the $P$ stock under section 362.32 If $P$ has no definable basis in its own stock, $S$ 's basis cannot be determined under the carryover provision of section $362 .{ }^{33}$ In that case the applicability of section 1032 to this transaction is not simply an equivalent characterization of the same tax events, because, unlike section 1032, section 351 and the reorganization provisions specify no alternative method for determining basis. ${ }^{34}$

2. The Parent Corporation's Basis in Its Own Stock. The Code provides no method for determining a corporation's basis in its own stock. Therefore the general rule that " $[t]$ he basis of property shall be the cost of such property"35 arguably applies. The corporation incurs virtually no cost in producing such stock, and assigning a zero basis to $P$ for its own stock is thus consistent with the language of the Code. A reported private letter ruling holding that a corporation's basis in its unissued and treasury stock is zero supports this view. ${ }^{36} S$ would therefore assume a zero basis in the transferred $P$ stock under the carryover provision of section 362 , which is triggered by any of the characterizations of the transaction described above. ${ }^{37}$

\section{B. Defects in the Zero Basis Theory}

The central inadequacy of the zero basis theory is that the concept of a basis to a corporation in its own stock is self-contradictory. The characterizations of the transfer that refer to section 362 for determination of basis in effect provide for the carryover of a basis that does not exist. If section 362 cannot apply, ${ }^{38} S^{\prime}$ s basis is determined under section 1012, which defines basis in property as the cost of acquisition. Only under the "contribution to capital" characterization is the cost of the $P$ stock to $S$ even arguably zero, and there is strong authority to the

31 A section 351 transaction has been ruled to exist simultaneously with (B) or (C) reorganizations in certain circumstances. Rev. Rul. 68-357, 1968-2 CuM. BULL. 144; Rev. Rul. 70-433, 1970-2 Cum. Butc. 82.

32 INT. Rev. CoDE \& 1032(b); Treas. Reg. \& 1.1032-1(d).

33 No provision of the Code renders section 362 technically inapplicable to this situation. Rather the difficulty is that application of the carryover basis provisions makes no sense unless there is a definable basis to carry over. See text and notes at notes 37-43 infra. Use of treasury stock rather than newly issued shares in the transfer has no effect on whether $P$ has a definable basis in its own stock. See text and note at note 43 infra.

34 See text and notes at notes $40-43$ infra.

35 INT. REv. CODE § 1012.

36 This ruling was reported in 1971 by Dubin, supra note 8 , at 858 .

37 See text and notes at notes 16-27 supra.

38 See text and notes at notes 32-33 supra. 
contrary. ${ }^{30}$ Moreover, the zero basis theory is at odds with the underlying economic reality of the transaction and the logic of the reorganization provisions of the Code.

1. The Parent's Nonbasis in Its Own Stock. The carryover provisions of section 362 cannot be applied if there is no basis to carry over, and the corporation can have a basis in its own stock only if that stock is "property." 40 It is apparent that $P$ 's stock, while it is held by $P$, lacks a crucial characteristic of property: its destruction or proliferation does not affect the value of the corporation. There can be no basis in something that neither has nor ever had any value, and $P$ 's stock has no value unless it is held by someone other than $P$. Therefore even if $P$ 's stock becomes property at the instant it is contributed to $S$, prior to that time there was no "property" susceptible of having any tax basis in $P$ 's hands. ${ }^{41}$ Section 362 requires $a$ basis; authorized but unissued stock apparently has no basis, and "no basis to carry over" is hardly equivalent to "zero basis." $S$ 's basis, therefore, must be determined by section 1012, without reference to any basis in the $P$ stock to $P$.

This result is also correct if the $P$ stock used in the transaction is treasury stock. ${ }^{42}$ In that case $P$ has reacquired its stock to extinguish a stockholder's claim against the corporation-not to acquire an asset. Treasury stock can have no basis to be carried over, because it is not property in any economic sense; rather it is a claim against the corporation held by the corporation itself. Calculating $S$ 's basis in the transferred $P$ stock according to the cost of acquiring the treasury shares is as inappropriate, therefore, as using the cost of the newly issued shares (zero) as a carryover basis. ${ }^{43}$

30 See text and notes at notes $54-61$ infra.

40 That property is a requisite for application of the carryover basis provisions is made clear by sections $362(a)(1)$, (a)(2), and (b).

41 See Committee on Corporate Taxation, supra note 8, at 152.

42 Although the Code does not define treasury stock, it is generally considered to be shares issued and then reacquired and held by the issuing corporation.

13 Revenue Ruling 62-217, 1962-2 CuM. BuLr. 59, implies that a corporation might have a cost basis for its shares where "[t]he cost basis of the treasury stock to the corporation" is less than fair market value on the date of distribution to its employees as compensation. The ruling held that the fair market value of such stock on the distribution date is deductible as compensation expense. This ruling is apparently the only post-1954 ruling to refer to cost basis for treasury shares. Several sections of the Code seem to indicate, however, that Congress intended treasury shares and newly issued shares to be treated identically. Section 1032 was formulated in 1954 to remove any differences in treatment of dispositions of a corporation's own shares. Section 317(b), which defines redeemed stock, also gives uniform treatment to stock whether it has been cancelled, retired, or held as treasury stock. In 1968 the enactment of Public Law No. 90-621 (Oct. 22, 1968), which 
In a different context a Treasury regulation precludes assignment of a zero basis in newly issued shares of a corporation's own stock precisely because such stock has no basis while held by the corporation. When a corporation distributes property to a corporate distributee (shareholder), the amount of the distribution, for purposes of calculating the dividend to the distributee, is computed as the lesser of (1) the fair market value of the property so distributed, or (2) the adjusted basis of such property "in the hands of the distributing corporation immediately before the distribution." 44 If the corporation's basis for its own shares were zero, then the amount of the distribution would be zero. The relevant Treasury regulation states, however, that "[i]f the property distributed consists of . . . stock of the distributing corporation treated as property under section $305(\mathrm{~b})$... the amount of such distribution shall be ... the fair market value of such stock."45 This regulation suggests the improvidence of literally applying statutory carryover rules such as those in section 362(a) where the "property" consists of authorized but unissued shares, which do not have a basis in the hands of the issuing corporation. At least in this context, the strong implication is that a zero basis is not to be used as the tax basis to a corporation in shares of its own stock. ${ }^{46}$

amended, inter alia, sections 362(b) and 358(e), changed those basis provisions to treat newly issued and treasury stock consistently.

Prior to the amendment, the two subsections had provided for carryover basis treatment where the property was acquired by "issuance of stock or securities." The Tax Court had held in Firestone Tire \& Rubber Co., 2 T.C. 827 (1943), that issuance of stock, within the meaning of the predecessor of section 358(e), meant original issuance only. The 1968 amendment effectively overruled Firestone by replacing the phrase, "issuance of stock" with the term "exchange of stock," thereby providing identical treatment for newly issued and treasury shares. The Senate Report states that the Act makes sections 358(e) and 362(b) applicable to acquisitions made with treasury stock of the acquiring corporation or its parent. S. ReP. No. 1653, 90th Cong., 1st Sess. 3 (1968). Consistent with this change, Proposed Treasury Regulations sections 1.358-4(b) and 1.362-1(b), 37 Fed. Reg. 7162 (1972), both provide retroactive treatment to treasury stock and unissued stock used in plans of reorganizations adopted prior to October 23, 1968 (the effective date of Public Law 90621). See text at note 111 infra.

44 INT. REv. CODE \& 301(b)(1)(B).

45 Treas. Reg. \$ 1.301-1(d), T.D. 7084, 1971-1 Gum. BuLc. 84. An illustration of the applicability of this regulation was offered by the Committee on Corporate Taxation, supra note 8, at 152. A corporation distributed newly issued shares of its stock to its preferred shareholders (one of which was a corporation) in discharge of preference dividends for the current year or preceding year. Such a distribution was made taxable by former section $305(b)(1)$. Code section 305(b) was amended and expanded, however, by Public Law No. 91-172, section 421(a) (Dec. 30, 1969). The accompanying 1969 Treasury Regulations, approved by Congress in the 1969 amendments to section 305, broaden the coverage of former section $305(\mathrm{~b})(\mathrm{l})$, and, partially because of delayed effective dates, the abovementioned illustration may still be applicable. See B. BrTrker \& J. EustiaE, supra note 8, I 7.61, at 7-69.

46 Indeed, if Treasury regulation 1.301-l(d) had ruled that such stock has a zero 
The Tax Court has not recognized the principles that animate this strong implication. The court's application of the basis concept of section 1012 has yielded tax results difficult to reconcile with the economic substance of the transaction and has demonstrated the error of overcautious literalism in interpreting the Code. Relying chiefly on a recent revenue ruling, ${ }^{47}$ the court in Velma W. Alderman ${ }^{48}$ held that an individual transferor's own note has a basis of zero rather than an undefined basis for purposes of section 357(c), which provides for recognition in certain transfers to controlled corporations. ${ }^{49}$ The court reasoned that, because the taxpayer incurred no cost in making the note, its basis to her was zero. Under this definition of "cost," a corporation similarly incurs almost no cost in printing its shares of stock, and section 1012 would compel a zero basis.

The function of the basis concept is to separate, upon disposition, that part of the value of property that constitutes investment from the part that constitutes gain or loss. The transferor in Alderman did not, in any significant sense, create "property" by executing a note. An obligation to oneself, unless held by another, has no value, and surely no basis-rather than a basis of zero-to the person who is both obligor and obligee. Alderman has been justly criticized as a mechanical application of the Code's basis provisions. ${ }^{50}$ The decision ignores the underlying purpose of the provisions and should not be extended. ${ }^{51}$

2. Applicability of Section 1012 to the Characterizations of the $\mathrm{P}$ to $S$ Transfer. The absence of any basis to $P$ in its own stock renders

basis for purposes of section $301(b)(1)(B)$, then the amount of the distribution would be zero, and the amount treated as a dividend would be zero. This result would make section 305(b)(1), as enacted prior to the 1969 amendment, superfluous and meaningless. Treasury Regulation section $1.301-1$ (d) can be reconciled with a zero basis determination under section 362 , however, if maximization of revenue is the policy underlying both provisions. A carryover basis of zero under section 362 gives the lowest possible basis for depreciation purposes and allows the maximum amount of gain to be recognized on a taxable exchange of such property or stock. Similarly, a fair market value determination for stock distributed under section $301(\mathrm{~b})(1)(B)$ subjects a higher amount to dividend treatment under section 301(c).

47 Rev. Rul. 68-629, 1968-2 Cun. BuLx. 154.

4855 T.C. 662 (1971).

49 INT. REv. CODE \& $357(c)(1)$ provides in part: "In the case of an exchange-(A) to which section 351 applies, ... if the sum of the amount of the liabilities assumed, plus the amount of the liabilities to which the property is subject, exceeds the total of the adjusted basis of the property transferred pursuant to such exchange, then such excess shall be considered as a gain from the sale or exchange of a capital asset or of property which is not a capital asset, as the case may be."

50 See generally Barnett, Problems in Incorporating the Going Business, 59 A.B.A.J. 1190 (1973); Note, 85 HaRv. L. REv. 880 (1972).

51 B. BrrTKER \& J. Eustrce, supra note 8, 73.07 , at $3-26$, states that section 357 (c) is a restriction on the general xule of section $357(a)$, requiring recognition of gain by the 
the characterization of the transfer unimportant. Even if the transaction satisfies the requirements of section 351, and thus is termed a transfer to a controlled corporation, the inapplicability of section 362 means, according to the regulation under section 1032,62 that $S$ 's basis is determined by the residual basis provision of the Code, section $1012 .{ }^{53}$ Similarly, even if the difficulties of characterizing the transfer from $P$ to $S$ as "in connection with a reorganization" are overcome, $S$ 's basis cannot be determined under section 362. In either case, $S$ assumes a cost basis under section 1012, rather than a carry-over zero basis, in the stock it receives from $P$.

If $P$ receives no $S$ stock in the transaction, the transfer of $P$ stock is a contribution to capital, ${ }^{54}$ and therefore $S$ 's basis, ordinarily determined under section 362, is the cost of the property acquired, as described in section 1012. In this case, however, cost basis and zero basis may appear to be equivalent because, unlike the section 351 and reorganization-related transfers, the contribution to capital involves no transfer from $S$ to $P$. Arguably $S$ 's cost for the $P$ stock it receives is zero. Despite the superficial plausibility of this method of determining cost basis, the tax treatment of other, similar transactions suggests that the cost to $S$ of the $P$ stock is a nonzero amount.

A recently proposed Treasury regulation adopts a legal fiction in characterizing direct transfers of a parent corporation's stock by the parent to an employee of its subsidiary. ${ }^{55}$ The proposed regulation provides that the transfer is to be construed as three steps: (1) a contribution of cash by the parent to the subsidiary; (2) a purchase of the parent's stock by the subsidiary at its full market value; and (3) a transfer of such stock by the subsidiary to its employee. This imputation of steps transforms a contribution of the parent's stock into a cash purchase of such stock, and section 1012 would then seem to require a cost basis equal to the amount of the cash.

The same result obtains where property is acquired without con-

transferor when the transferee corporation receives property that has encumbering liabilities in excess of such property's adjusted basis. Revenue Ruling 68-629, 1968-2 Cum. Bull. 154, in finding that a transferor's own note has a zero basis for purposes of section 357 (c), merely attempts to prevent the transferor from evading section (c) by padding the adjusted basis of the property transferred.

52 See note 14 supra.

53 "The basis of property shall be the cost of such property, except as otherwise provided in this subchapter and subchapters $C$ (relating to corporate distributions and adjustments), $K$ (relating to partners and partnerships), and $P$ (relating to capital gains .....)" INT. REv. CODE $\$ 1012$.

54 The transaction would not be characterized as a contribution to capital under the constructive exchange approach discussed earlier. See note 16 supra.

65 Proposed Treas. Reg. § 1.83-6(d)(1), 36 Fed. Reg. 10793 (1971). 
sideration. In the absence of a carryover basis statute, the recipient's basis in gifts, ${ }^{56}$ contributions to paid-in surplus of corporations, ${ }^{57}$ contributions to capital of partnerships, ${ }^{58}$ and certain transfers to trusts ${ }^{59}$ has been held to be the fair market value of the property received. ${ }^{.0}$ Although each of these instances is now controlled by a statutory provision requiring a carryover basis, ${ }^{61}$ they lend support to the contention that fair market value-rather than zero-is the appropriate measure of cost for basis purposes where true cost cannot be determined because the transferor receives nothing in return.

3. Tax Policies and the Underlying Economics of the Transaction. The zero basis theory is not only difficult to reconcile with the relevant interrelated Code provisions as judicially interpreted, but also inconsistent with the economic events represented by a triangular acquisition and the tax policies that animate the reorganization provisions. Moreover the zero basis theory excessively emphasizes artificial distinctions based on the purely formal denomination of the transaction.

There are several transactions very similar to the transfer of $P$ stock to $S$ that yield dramatically different tax consequences under the zero basis theory. If, for example, $P$ contributes cash instead of its own stock to $S,{ }^{62}$ and the second step in the triangular exchange triggers recognition to $T$ and $S, S$ would take a basis equivalent to the amount of the cash. ${ }^{63}$ Where $P$ stock has been transferred to $S$, defining $S$ 's basis in the $P$ stock as zero only penalizes nonliquidity on the part of $P$ or compels $P$ to increase liquidity by selling on the market the $P$ stock it intended to transfer to $S$. Similarly if the parent in an attempted triangular reorganization had directly transferred its own stock to the target corporation and the latter's assets or stock were routed to the parent and then dropped into the subsidiary, failure of the transaction to achieve tax-free status would result in no recognition of gain or loss to either the parent or the subsidiary. $P$ would be protected by section 1032. $S$ very likely would not be considered the acquiring corporation, ${ }^{64}$ and further, any property dropped down from $P$ would be a con-

\footnotetext{
s6 Rice v. Eisner, 16 F.2d 358 (2d Cir. 1926), cert. denied, 273 U.S. 764 (1927).

57 Rosenbloom Finance Corp., 24 B.T.A. 763, 774 (1931), rev'd, 66 F.2d 556 (3d Cir.), cert. denied, 290 U.S. 692 (1933).

58 Helvering v. Walbridge, 70 F.2d 683 (2d Cir.), cert. denied, 293 U.S. 594 (1934).

59 Bankers Trust Co., 24 B.T.A. 10 (1931).

Bo It also has been suggested that recipients of contributions of capital to corporations take a cost basis in such contributions equal to their fair market value-absent a carryover basis statute. See S. REP. No. 398, 68th Cong., 1st Sess. 18 (1924).

61 Committee on Corporate Taxation, supra note 8, at 153 .

62 INT. REv. CoDE § 118.

63 Id. § 362(a)(2).

of The acquiring corporation here would be $P$. See $i d . \$ \$ 368(a)(1)(B),(a)(1)(C)$.
} 
tribution to capital. ${ }^{65}$ A zero basis to the subsidiary for the $P$ stock, however, coupled with a finding of recognition to the subsidiary on its exchange of $P$ stock to $T$, would, in a nonqualifying triangular acquisition, cause recognition of gain equal to the fair market value of the $T$ assets or stock acquired. It is difficult to justify this difference.

The zero basis theory also conflicts with the principles at work in the Code provisions concerning stock transfers in general ${ }^{66}$ and reorganizations in particular. ${ }^{67}$ By providing for nonrecognition on the transfer of property to a controlled corporation and for a carryover of the transferor's basis, sections 351 and 362, for example, contemplate that the previously unrecognized gain or loss will be recognized by the transferee corporation $(S)$ when the latter disposes of the property received. ${ }^{68}$ In this situation, however, the transferor $(P)$ had no gain to be recognized because it would have realized no gain on a sale to an outside buyer pursuant to section 1032. The purpose of sections 351 and 362 is to preserve a gain that would have been recognized, ${ }^{68}$ whereas assigning a zero basis to $S$ would create an artificial gain that would not have been taxable to $P$ if the latter had disposed of its own stock.

Congress did not intend such uneven tax consequences from different methods of routing the same reorganization transaction:

[The House Ways and Means Committee's] bill is designed to insure that the same tax consequences result from the different types of transactions which are available to accomplish substantially the same result. This correlation is important not only because it promotes clarity and certainty in the law but also because it insures that taxpapers cannot, by choosing the type of transaction, in effect choose the type of tax for which they are liable. ${ }^{70}$

65 See note 12 supra.

66 E.g., INT. REv. CODE § 1032.

67 E.g., id. $\$ \S 368,354,361$.

68 See Easson v. Commissioner, 294 F.2d 653 (9th Cir. 1961); B. Brrtker \& J. Eustice, supra note 8, I 3.17, at 3-57, 3-58. The purpose of sections 351 and 362 is to prevent taxpayers from stepping up their basis in property by a change only in the form of ownership-such as incorporation. See Republic Steel Corp. v. United States, 40 F. Supp. 1017 (C. Cl. 1941). Thus, although sections 1032 and 351 may both be construed to fit this transaction, the underlying policy of section 351 is inappropriate here, and therefore section 351 arguably does not "apply" to such a transfer, secton 362(a)(1) notwithstanding. Compare Rooney v. United States, 305 F.2d 681, 686 (9th Cir. 1962) (section 482 controls when in conflict with section 35I) and B. BITTKER \& J. EustraE, supra, I 3.17, at 3-57 (section 301 may control in certain overlaps with section 351(b)) with Commissioner v. Stickney, 399 F.2d 828 (6th Cir. 1968).

69 See Easson v. Commissioner, 294 F.2d 653 (9th Cir. 1961); B. BitTkER \&. J. Eustice, supra note 8 , शf 3.17, at 3-57, 3-58.

70 H.R. REP. No. 1337, supra note 10, at 39 . 
Although the form of a reorganization often has important tax consequences, ${ }^{71}$ the Gode provisions should not be construed so that a slight change in the routing of property in a triangular acquisition yields such devastatingly different effects. ${ }^{72}$ Rather the Service should, and in other contexts often does, incline toward allowing restructuring a transaction to avoid the zero basis problem. ${ }^{73}$

\section{The Cost or Fair Market Value Alternative}

Although there is no more conclusive authority for cost or fair market value $^{74}$ basis than for zero basis, the former alternative is more in harmony with the relevant Code provisions and preserves the economic logic of the transaction. The Service has ruled that a purchase of shares of the parent's stock on the open market by its wholly-owned subsidiary results in a nonzero basis to the subsidiary..$^{75}$ In that revenue ruling the facts of the hypothetical case included a sale of $P$ stock by $S$ to outside interests at a gain. The ruling held that section 1032 did not protect $S$ from recognition of gain, and that "the sale of such stock to out-

71 E.g., compare Rev. Rul. 70-107, 1970-1 CuM. BuLl. 78 (no (C) reorganization where $S$ exchanges $P$ stock for $T$ assets, because $P$ had assumed some of $T$ 's liabilities; $P$ held not to be the acquiring corporation) with Rev. Rul. 70-224, 1970-1 CuM. BuLL. 79 ((C) reorganization allowed where $P$ transfers its stock to $T$, which in turn transfers its assets directly to $S ; P$ held to have control over the assets, and $P$ 's assumption of liabilities is permitted).

72 Where consideration for the acquisition is stock in the parent, the tax result should not turn on whether the assets of the acquired company first move to the parent and then down to a controlled subsidiary, or rather move directly to the subsidiary. Blum, Corporate Acquisitions Under the Income Tax: Another Approach, 50 TAXEs 85, 89 (1972). See also text at note 70 supra.

73 Examples of restructuring, in addition to Proposed Treasury Regulation section 1.836(d), 36 Fed. Reg. 10793 (1971), include Revenue Ruling 57-278, 1957-1 CuM. BuL.. 124 (transitory ownership of assets in a (C) reorganization by wholly-owned subsidiary effectively disregarded; (B) reorganization without the use of the newly created subsidiary would achieve similar results); Revenue Ruling 67-448, 1967-2 Cum. BuL.. 144 (transitory existence of newly created subsidiary disregarded and transaction considered a (B) reorganization; result not negated merely because "the transaction was cast in the form of a series of interrelated steps"); Revenue Ruling 70-224, 1970-1 CuM. BuLc. 79 (transaction treated as if there had been a direct acquisition by $P$, followed by a "drop down" to $S$ of the $T$ assets). See note 71 supra; Rev. Rul. 73-28, 1973 INT. REv. But.. No. 3, at 6 (P stock received by $S$ constitutes voting stock so that a (B) reorganization exists, regardless of S's inability to vote such stock); Rev. Rul. 73-233, 1973 INT. Rev. BuLl. No. 22, at 6 (stock contribution to capital of corporation by shareholder, prior to a merger, recharacterized as transfer to other shareholders). On the problem and necessity of using "net effect" analysis in various triangular exchanges, see Freling, Current Problems in Subsidiary Mergers and Other Triangular Reorganizations, supra note 8, at 387.

74 Although the Code provisions use only the term "cost," determination of $S$ 's cost basis in the stock acquired from $P$ requires reference to its fair market value. See text and notes at notes 91-97 infra.

75 Rev. Rul. 70-305, 1970-1 CuM. BurL. 169. 
side interests is a transaction resulting in a gain or loss."78 If $S$ took a zero basis in its purchases of $P$ stock on the open market, it would never recognize a loss on a later sale. Moreover, if a zero basis were assigned, the ruling would state that $S$ recognizes a gain equal to the proceeds of the sale of the $P$ stock to the outside interests. In light of the inappropriateness of the zero basis in this context, the basis should be $S$ 's cost, as provided by section 1012.77 The basis of $P$ stock purchased by $S$ from $P$ can be characterized similarly. The Service apparently does not distinguish the two transactions, and there is no apparent reason to determine $S$ 's basis according to the identity of the seller. ${ }^{78}$ Because the carryover basis provision of section 362 is inapplicable, the $P$ stock received by $S$ should have a cost basis, irrespective of any transfer of cash or stock from $S$ to $P$. The wisdom of this result is especially clear with respect to transfers of stock from $S$ to $P$ in light of the economic insignificance of that event. ${ }^{79}$

Where the transfer of $P$ stock is a contribution to capital, there is little ambiguity in determining $S$ ' $s$ basis because there is no measure available other than the fair market value. Where cash is transferred from $S$ to $P$, however, the nominal value of what $S$ has paid for the $P$ stock is somewhat artificial in light of $P$ 's control over the price of its stock to $S$. Routine acceptance of the parties' representation of the transaction would permit $S$ 's basis to be manipulated easily. There is, however, a relatively simple remedy for this difficulty.

If the subsidiary paid more to the parent for the latter's stock than its fair market value the transfer could be regarded as a dividend or a distribution of capital to the parent, to the extent of such excess. ${ }^{80}$ This would produce a basis in the $P$ stock equal to its fair market value. If $S$ has paid less than fair market value, the transaction might be viewed in one of two ways to produce a basis equal to fair market value. Assume that $P$ stock is actively traded at $\$ 5.00$ per share, and $P$ sells 100 shares of $P$ stock to $S$ for $\$ 4.00$ per share. Assume further that this sale will

76 Id. (emphasis added).

77 The cost basis approach to purchases of parent stock by a subsidiary had much support even before it was adopted by the Service. The Committee on Corporate Taxation concluded, one year before Revenue Ruling 70-305, 1970-1 Cum. BuLL. 169, that a cost basis is appropriate for stock of the parent corporation held by its subsidiary, at least in the case where the subsidiary purchased the stock at current fair market value. See Committee on Corporate Taxation, supra note 8 , at 151 .

78 Rev. Rul. 70-305, 1970-1 Cum. BuLx. 169 (official headnote).

79 While the additional stock of the parent enriches the subsidiary, the additional stock in the subsidiary does not and cannot in any way enrich the parent. Joy Mfg. Co. v. Commissioner, 230 F.2d 740, 742 (3d Cir. 1956); cf. Josephson v. Commissioner, 6 T.C.M. 788, 789 (1947).

80 See INT. REv. CODE $\S 482$; text and note at note 91 infra. 
have no significant effect on the current market price of $P$ stock. The transaction can be viewed as a contribution of $\$ 100$ from $P$ to $S$ and a purchase by $S$ of the shares for the market price of $\$ 5.00$ per share. This view is analogous to the proposed characterization of the first two steps in the transaction in which the parent gives its own stock to its subsidiary's employees. ${ }^{81}$ Another view of the transaction is that the subsidiary purchased 80 shares at the market price and the remaining 20 shares were received by the subsidiary from the parent as a contribution to capital. Under this approach, the basis of the 20 contributed shares would also be the fair market value.

If the subsidiary paid less to the parent than the fair market value of the parent's stock, however, it is unlikely that the subsidiary's basis in the stock would be increased to fair market value. $S$ would therefore recognize a larger gain (or smaller loss) on a subsequent taxable exchange than if the basis had been equal to market value. Because $P$ controls the sale price of its $P$ shares to $S$, however, recognition of a larger gain by $S$ can be avoided by a prior contribution of cash to $S$ returned to $P$ as part of the purchase price, which presumably would be raised by the amount of the cash contribution. If $P$ cannot raise the cash to make this temporary contribution, $S$ cannot avoid the lower cost basis.

Exchanges of stock between $P$ and $S$ could be treated in the same manner as cash purchases of $P$ stock by $S$. If $S$ is a newly formed subsidiary, as often is the case, ${ }^{82}$ it may have virtually no assets, liabilities, or prior record of performance. The fair market value of such stock at the crucial time when the exchange with $P$ occurs is likely to be zero. $^{83}$ Even if $S$ was created long before the exchange, the inactive

81 See text and note at note 55 supra.

82 E.g., Rev. Rul. 67-448, 1967-2 Cum. BuLl. 144; Rev. Rul. 57-278, 1957-1 Cum. Buld. 124; Rev. Rul. 56-100, 1956-1 Cum. Bull. 624.

83 That the $S$ stock has never been listed on an exchange, has never been traded in a dealer's market, and has never been sold does not necessarily establish that the $S$ stock has no value for income tax purposes. French Dry Cleaning Co. v. Commissioner, 72 F.2d 167 (5th Cir. 1934). That case, however, focused on a pre-existing operating corporation, not a newly formed shell, as is often used in triangular reorganizations.

The primary evidence of the fair market value of corporate stock has been described as the price willing purchasers would pay to willing sellers on the open market, even though the assets of the corporation do not reflect such values. Hazeltine Corp. v. Commissioner, 89 F.2d 513 (3d Cir. 1937); Commissioner v. Robertson, 75 F.2d 540 (6th Cir.), cert. denied, 295 U.S. 763 (1935). The Committee on Corporate Taxation, supra note 8, at 154, reasons that the fair market value of the $P$ shares will, in actual practice, "often be identical" to that of the $S$ shares, "although these two values may differ in theory." The fair market value of the $S$ stock at the time of the transfer may be zero, because very frequently $S$ is a newly formed shell. To avoid this discrepancy, the Service stipulated in Revenue Ruling 73-28, 1973 INT. REv. BuLL. No. 3, at 6, that "[t]he fair market value of 
stock of a wholly-owned subsidiary is not likely to have a readily ascertainable market value. The $P$ stock, on the other hand, is likely to be of substantial value, especially if such stock is to be the major inducement to the target corporation in a triangular acquisition. Even if the general rule were modified in the exchange of stock between $P$ and $S$ so that the value of the transferred $S$ stock measured immediately after the exchange was compared to the value of the $P$ stock received, the two values might not be identical. Assume that $S$ was previously formed by $P$, and the latter received all the shares of $S$ 's stock-issued without par value-in exchange for a small contribution of cash. If, a few years later, $P$ exchanges some of its stock for a few more shares of $S$ stock, ${ }^{84}$ the additional stock of the parent enriches the subsidiary; but the additional stock of the subsidiary cannot enrich the parent. ${ }^{85}$ Thus the additional $S$ stock transferred to $P$ has no value to $P$. The $S$ stock exchanged might have some value to an outsider, but this value is not a useful measure of $S$ 's basis where $P$ is the recipient.

These situations, however, can be treated like the case of the subsidiary that purchases the parent's stock at a value below market value. There the fair market value of the $P$ shares was shown to be an appropriate basis to $S .^{86}$ The courts have long held that where property is received in exchange for the stock of a corporation, the "cost" to the issuing corporation is equal to the market value of the stock transferred. ${ }^{87}$ Where, as here, the market value of the stock cannot be determined, however, the "cost" to the issuing corporation is equal to the fair market value of the property received ( $P$ stock). ${ }^{88}$ Even if no stock

the [parent] stock was equivalent to the fair market value of the [second-tier subsidiary] as determined by an independent appraiser."

84 The time lapse hypothesized would very likely preclude construing the two unrelated transfers of $S$ stock to $P$ as one, so as to transform these steps into an ordinary triangular reorganization. But see D.W. Douglas, 37 B.T.A. 1122 (1938); note 26 supra. There is no corporate law prohibiting the subsidiary from exchanging any number of shares that it is authorized to issue by its corporate charter. Where, as here, no-par stock is being transferred by $S$, the latter's board of directors fixes the consideration to be received for such shares. E.g., ABA-ALI MOdel. Bus. CoRp. AGT $\$ 18$ (2d ed. 1971).

85 See note 79 supra.

86 See text and notes at notes 80-81 supra.

87 Forstmann v. Rogers, 128 F.2d 126 (3d Cir. 1942); Hazeltine Corp. v. Commissioner, 89 F.2d 513 (3d Cir. 1937); McCallum Gauge Co., 32 B.T.A. 544 (1935). See Rev. Rul. 56100, 1956-1 Cum. Btrc. 624 .

88 In an arm's length transaction, the market value of one of the properties in an exchange is frequently unknown, but is established by the known value of the other. E.g., Swiss Oil Corp., 32 B.T.A. 777, 787 (1935). Here, the value of the $P$ stock is the known factor. Using the $\dot{P}$ stock as the benchmark rather than the $S$ stock is dictated "purely [by] a valuation problem, and should not obscure the underlying definition of cost." Greenbaum, The Basis of Property Shall Be the Cost of Such Property: How Is Cost Defined?, 3 TAX L. REv. 351 , 370 n.64 (1948). 
or cash flows from $S$ to $P$ in the transaction, so that the transfer of $P$ stock is a contribution to capital, application of a cost basis, measured by the fair market value of the $P$ shares, is analytically sound. As noted earlier, ${ }^{89}$ in many contexts contributions received without consideration have a nonzero basis to the recipient as measured by their fair market value.

Because a transfer of $S$ shares to $P$ contributes nothing of value to $P$, that part of the transaction might be disregarded altogether. In that event, $S$ 's basis in the $P$ shares could be determined as if it had received a contribution to capital in the amount of the fair market value of the $P$ stock.90

As the foregoing discussion indicates, assigning the subsidiary a cost basis in the $P$ stock received from its parent requires reference to the fair market value of the $P$ stock. Adjustments in basis to reflect fair market value could very likely be predicated upon section 482 of the Code, which empowers the Service to reallocate gross income in order to prevent evasion of tax or to reflect income more clearly..$^{.1}$

A fair market value basis for the $P$ stock transferred to $S$ is consistent with the economic meaning of the transaction. If, instead of contributing shares to its subsidiary, the parent sold its shares in the market and contributed the cash proceeds, the parent would recognize no gain or loss, and the subsidiary's basis in the contribution would be the amount of cash received.92 If $S$ then purchased in the market the same number of shares as $P$ had sold-assumedly at the same price-it would have established a fair market value basis in three steps. ${ }^{93}$ The policy of not permitting routing to alter the tax consequences of a transaction $^{94}$ supports giving $S$ a fair market value basis for $P$ stock contributed directly by $P$.

89 See text and notes at notes 56-61 supra.

90 But see Rev. Rul. 73-246, 1973 InT. REv. BuLL. No. 23, at 8 (discussed at note 22 supra). The Service maintains, however, that an additional issuance of stock by a whollyowned corporation to its sole shareholder, in exchange for property, does have relevance under the tax laws (section 1032(a) grants the corporation nonrecognition). Id.

91 E.g., National Securities Corp. v. Commissioner, 137 F.2d 600 (3d Cir.), cert. denied, 320 U.S. 794 (1943); Treas. Reg. § 1.482-1(d)(5), T.D. 6952, 1968-1 CuM. Bull. 222. As to parent-subsidiary transactions, see Loening, Section 482 Allocations Resulting in the Creation of Income or in Constructive Dividends to Shareholders, N.Y.U. 30TH INST. ON FED. TAx. 1247, 1262-9 (1972). The authority granted by Code section 482 extends to transactions that would otherwise be granted nonrecognition status under section 351. E.g., Rooney v. United States, 305 F.2d 681 (9th Cir. 1962). See generally Berger, Gilman, \& Stapleton, Section 482 and the Nonrecognition Provisions: An Analysis of the Boundary Lines, 26 TAX LAWYER 523 (1973).

92 INT. REv. CODE $\$ \S 1032,362($ a)(2).

93 Cf. Proposed Treas. Reg. \& 1.83-6(d), 36 Fed. Reg. 10793 (1971).

84 See Blum, supra note 72, at 89. 
The fair market value approach also has the advantage of conforming the tax consequences to the economic result where $S$ subsequently sells the $P$ shares contributed to it. If the sale is made by $S$ immediately after it has received the shares from $P$, it will produce a recognition of gain or loss..$^{95}$ The appreciation or depreciation in value that occurred during the interval in which $S$ actually held the $P$ stock would very likely be zero, and $S$ would recognize no gain. The assignment of a zero basis to $S$ for the $P$ stock, however, would result in recognition of a gain to $S$ equal to the entire value of the $P$ stock contributed. Although in other situations a gain recognized by one party might be attributable to the prior owner because of the carryover basis provisions, the policy of those provisions is to assure that a gain that would have been recognized by the prior owner upon a taxable disposition of the property is preserved in the hands of the transferee, rather than destroyed. This policy is inapplicable to a contribution of $P$ stock to $S$; $P$ never would have recognized gain on a disposition of its stock in exchange for property because of the nonrecognition provisions of the Code. ${ }^{96} \mathrm{~A}$ basis other than fair market value for the transferred $P$ stock thus creates a wholly artificial gain, rather than properly preserving one that had previously accrued to $P .{ }^{.7}$

\section{Basis to the Parent in the Subsidiary's Stock}

The Code offers no explicit guidance for determining the parent corporation's basis in stock of its subsidiary received in exchange for either cash or the parent's stock. The determination must be made under the provisions for substitute, carryover, and cost (as measured by fair market value) basis. Because of the difficulties posed by the zero basis theory, the last of these is the most appropriate characterization where $P$ stock is exchanged for $S$ stock. A substitute basis is appropriate where $P$ purchases the stock for cash. ${ }^{98}$

95 Rev. Rul. 70-305, 1970-1 Cum. BuLr. 169; text and notes at notes 75-76 supra.

96 E.g., INT. Rev. Code § 1032.

97 See text and notes at notes 68-69 supra. Moreover, if $P$ ultimately disposes of $S$ in a transaction triggering recognition, $P$ will recognize gain or loss equal to the fair market value of property received by it, less $P$ 's basis in its stock in $S$. If $P$ 's investment in $S$ stock was sold immediately after a taxable transaction between $S$ and $T$, as hypothesized above, then under the zero basis method $S$ would recognize gain equal to the value of the $T$ assets or stock, and $P$ would recognize gain equal to the value of $S$. If $S$ had been a newly formed shell, its value would be approximately equal to the fair market value of the $T$ assets or stock that it received. Thus the $T$ assets or stock are effectively taxed twice; at current maximum corporate rates of 48 percent, the total tax paid on these two taxable transactions would equal 96 percent of the value of the $T$ assets or stock.

$98 \mathrm{In}$ this situation, the difference between cost and substitute bases is purely formal, because-unlike other "assets"-cash carries its own basis. 
In a triangular reorganization the subsidiary's transitory possession of the parent's shares is insignificant. ${ }^{99}$ The triangular transfer is thus properly treated in the same way as a transfer of stock by $P$ to $T$ in exchange for $T$ 's assets or stock, ${ }^{100}$ followed by $P$ "dropping down" the assets into $S$ either as a contribution to capital or in exchange for $S$ 's shares. Although the Code does not contain any express provision for determining $P$ 's basis for the $S$ shares when the $P$ shares are transferred directly to $T$, it is widely considered to be equal to the basis to $T$ in its assets or to $T$ 's shareholders in their stock. ${ }^{101}$

Determining $P$ 's basis is more problematic where the $S$ stock was transferred to $P$ in exchange for $P$ stock at a time when no plan to use the $P$ stock in a triangular reorganization had been formulated. Viewing the exchange between $P$ and $S$ as a step separate from the reorganization brings into sharper focus the various methods for computing $P$ 's basis in the $S$ stock.

\section{A. Substitute Basis}

If the parent purchases the subsidiary's shares for cash, the substitute basis rule ${ }^{102}$ can be applied without difficulty because the basis is equal

98 For example, if the three-way transfer is pursuant to a plan of reorganization, INT. REv. CoDE $\$ 368$, the role of the subsidiary is ignored.

100 Rev. Rul. 64-73, 1964-1 Cum. Buls. 142; Rev. Rul. 57-278, 1957-1 Cum. Burc. 124. This treatment may depend on classification of the parent as the "acquiring" corporation. Rev. Rul. 70-107, 1970-1 Cum. BuLl. 78.

101 The policy of the Service reportedly is that $P$ 's basis for $S$ includes the basis of the assets or stock carried over from T.E.g., Committee on Corporate Taxation, supra note 8 , at 149; Cornfeld, supra note 8, at 1358; Levin, supra note 8, at 785-86; Sapienza, supra note 8 , at 808 . This position can be justified in the case of a contribution to capital: the $P / T$ reorganization gives $P$ a carryover basis in the $T$ assets or stock under section 362(b), and $P$ 's contribution of them to $S$ would increase $P$ 's basis in $S$. INr. REv. CoDE $\S 1016($ a). See also Treas. Reg. \& 1.118-1 (1956). The increase probably should equal the basis of the property ( $T$ stock or assets) contributed, because the contribution is voluntary and nontaxable. B. BrTrker \& J. Eustice, supra note 8, f 3.14 at $3-51$. The same result should occur when a $P / T$ reorganization is followed by a section 351 exchange between $P$ and $S$, because section 358(a) provides $P$ with a substitute basis for the $S$ stock received, equal to the basis of the $T$ stock or assets transferred to the subsidiary. The exception in section 358(e) is inapplicable because $P$ is not transferring its own stock to $S$. The drop down of $T$ assets or stock from $P$ to $S$ does not disqualify the $P / T$ reorganization. INr. Rev. CoDE $\$$ 368(a)(2)(C). Cornfeld, supra note 8, at 1358, assumes that $P$ 's basis in its $S$ stock would be as described above even in the case where the subsequent exchange by $S$ of the $P$ stock for $T$ stock or assets does not qualify as a tax-free exchange.

102 "In the case of an exchange to which section 351 ... applies-(1) The basis of the property permitted to be received under such section ... shall be the same as that of the property exchanged ... [subject to certain adjustments]." INr. REv. CoDE $\S 358(a)(1)$. "In the case of an exchange to which section 351 ... applies in which . . . only nonrecognition property is received, the basis of all the stock and securities received in the exchange shall be the same as the basis of all property exchanged therefor." Treas. Reg. § 1.358-1(a), T.D. 6533, 1961-1 CuM. BuLL. 36. 
to the amount of the cash. ${ }^{103}$ There is, however, considerable potential for manipulation. $P$ controls the number of $S$ shares to be acquired for the cash it pays. Manipulation is not a problem if $S$ is a subsidiary newly created by this transaction because the number of shares received by $P$ has no significance. Where $S$ is a pre-existing corporation, however, $P$ could take a basis in the more recently acquired shares higher or lower than the current fair market value of the $S$ stock by manipulating the timing of gain number of shares received. By this device $P$ could control the timing on subsequent disposition of its $S$ shares. ${ }^{104}$ If $P$ pays more than fair market value for the $S$ shares, ${ }^{105}$ the excess probably will be treated as a contribution to capital. ${ }^{106}$

In an exchange of $P$ stock for $S$ stock, section 351 would very likely provide nonrecognition treatment for $P$, assuming the definitional problems of characterizing $P$ 's stock as "property" can be surmounted.107 In that case, the substitute basis provisions would be applicable. If $P$ received only $S$ stock on the exchange, $P$ would then have a basis for the $S$ stock equal to the basis of the property ( $P$ stock) transferred to $S .108$

The substitute basis rule causes problems, however, if-as argued earlier-the parent's stock has no basis (as opposed to zero basis) in the parent's hands. ${ }^{109}$ It is meaningless to say that the substitute rule provides the parent with "no" basis for the subsidiary's stock, because no

103 The term "property" in section 351(a) has been held to encompass money. E.g., George M. Holstein III, 23 T.C. 923 (1955); Rev. Rul. 69-357, 1969-1 Cum. BuLc. 101. Thus the substitute basis rule of section 358 applies. INT. REv. Cone $\$ 351(\mathrm{e})(2)$.

104 For example, assume $P$ contributes $\$ 5.00$ to a newly created $S$ in exchange for its sole share of stock, and later $P$ contributes $\$ 7.00$ to $S$ for one additional share. $P$ takes a substitute basis in the $S$ shares under Code sections 351 and $358-\$ 5.00$ for share one, $\$ 7.00$ for share two. The total value of $S$ corporation is $\$ 12.00$. If $P$ sells one-half of its stock in $S$-one share-it will realize $\$ 6.00$ as proceeds. If share one is sold, $P$ recognizes a gain of \$1.00; if share two is sold, $P$ recognizes a $\$ 1.00$ loss. INT. REv. CoDE $\$ \S 1002,1001$.

105 It may be difficult to compute the excess above the fair market value of the $S$ shares, which must be determined at the time of each purchase of $S$ stock by $P$. If $S$ is a whollyowned subsidiary, the Service may find no market-determined value for measuring the contribution to capital. The fair market value of the $S$ shares is unavailing, because the Service often cannot determine whether the value of the shares has fluctuated since $P$ 's purchase. If $P$ paid $S$ below current market, a dividend-type distribution would be found. Loening, supra note 91; see note 80 supra.

108 See generally text and notes at notes 80-81 supra. The parent and subsidiary might be able reciprocally to manipulate their cost bases in each other's stock. If $P$ purchases shares of $S$ stock from the Iatter for cash, and $S$ subsequently uses that cash to purchase an equivalent amount of $P$ stock from $P$, the net effect is an exchange of stock between $P$ and $S$, producing cost bases to each for the shares of the other.

107 See text at notes 20-21 supra. It can be contended that section 351 does not "apply" because it is not essential to provide nonrecognition. See text and note at note 68 supra.

108 INT. REv. CodE § 358.

109 See text and notes at notes $40-43$ supra. 
basis implies an undetermined basis. Section 358(e) meets this problem by suspending the substitute basis provision of section 358 where the parent corporation acquires property in exchange for its stock.110 The 1968 amendment to section 358(e) makes clear that the exception applies to both treasury and newly issued stock. ${ }^{111}$

\section{B. Carryover Basis}

The regulations under section 358 state that in cases where section 358(e) precludes application of the substitute basis rule, section 362 and the regulations thereunder should be consulted.112 Therefore the carryover basis rule of section 362 would seem to apply and the basis of the $S$ stock in $P$ 's hands would be the same as in $S$ 's hands. Here too, however, the inapplicability of the basis concept to stock held by the issuing corporation means that the $S$ shares had "no" basis to $S .113$ A carryover basis therefore cannot be used to determine gain or loss on ultimate disposition by $P$ of the $S$ shares.

\section{Cost or Fair Market Value Basis}

The inappropriateness of the carryover basis provisions in an exexchange of $P$ stock for $S$ stock means that $P$ 's basis in the transferred $S$ shares is determined under section 1012, which provides for a cost basis. Where transfer of $P$ shares to $S$ is part of an exchange of stock between $S$ and $P$, the cost of the $S$ shares received by $P$ has long been held to be the fair market value of the $P$ shares at the time of their transfer to $S .114$

The cost or fair market value alternative would prevent manipulation by the parent in at least one situation. Assume that the parent earlier purchased shares of its own stock on the open market at prices both substantially above and below the current market price. If the parent sells the low-basis shares at the current market price, it will realize a gain, but that gain will not be recognized because of the provisions of section 1032. The parent might transfer the high-basis stock

110 "This section shall not apply to property acquired by a corporation by the exchange of its stock or securities (or the stock or securities of a corporation which is in control of the acquiring corporation) as consideration in whole or in part for the transfer of the property to it." INT. REv. CODE \& 358(e).

111 The amendment to section 358(e) was adopted shortly after the Service took a similar position in Proposed Treasury Regulation section 1.358-4, 33 Fed. Reg. 6163 (1968), which stated that "the term 'issuance of stock or securities' includes any transfer of stock or securities, including stock or securities which were purchased or were acquired as a contribution to capital."

112 Treas. Reg. \& 1.358-4 (1955).

113 See text and notes at notes $40-43$ supra.

114 See text and note at note 87 supra. 
held in its treasury to its subsidiary as either a contribution to capital or a transfer of property to a controlled corporation. If treasury stock is treated differently from newly issued shares ${ }^{115}$ and basis is calculated according to the amount of cash paid by $P$ in reacquiring its shares, $S$ would assume a high basis in the transferred $P$ shares if the carryover basis rule of section 362 applies. $S$ could then recognize a capital loss by selling the $P$ shares immediately at the current market price. ${ }^{116}$ Recognition of the subsidiary's loss might be prevented where it can be shown that the subsidiary's possession of the $P$ shares was transitory and should be disregarded, ${ }^{117}$ but there is no guarantee that the courts would accept this recasting of the transaction. Adoption of the cost or fair market value approach would eliminate this distinction.

The potential for manipulation that is present when $S$ stock is purchased for cash ${ }^{118}$ may also influence the way $P$ and $S$ accomplish an exchange of stock. By reducing or increasing the ratio of $S$ shares to $P$ shares, $P$ can manipulate its recognition of gains and losses if $S$ is a preexisting subsidiary. The favorable tax consequences resulting from these manipulations can be prevented by application of section $482 .{ }^{119}$

Determination of the parent's and subsidiary's bases in each other's stock by the cost or fair market value method is the most reasonable alternative possible under the present Code provisions, because it reduces the effect of form, routing, and timing on the tax consequences of the transaction. A quasi-treasury stock approach, however, which would require amendments to the Code, ${ }^{120}$ is perhaps most reflective of the economic events underlying the triangular transaction. Moreover, it is more easily administered than the cost or fair market value approach and yields more uniform results.

\section{The Quasi-Treasury Stock Variant of the Cost or Fair Market Value ApProach}

\section{A. Mechanics of the Quasi-Treasury Stock Variant}

Under the fair market value method of computing basis, any change in the value of the $P$ stock between the time of its transfer to $S$ and the transaction with $T$ produces no gain or loss to $P .{ }^{121}$ The gain or

115 Amendments to the Code indicate that treasury shares and newly issued shares should be treated identically. See INT. REv. CODE $\$ \$ 1032,358,362$; note 43 supra. There is no definitive indication, however, that the difference between treasury shares and newly issued shares is to be ignored in applying the cost basis principle of Code section 1012.

116 INT. Rev. CODE § 1222.

117 See text and note at note 100 supra.

118 See text and notes at notes 104-06 supra.

110 See text and note at note 91 supra.

120 See text and notes at notes 136-4I infra.

121 See INT. REv. CODE § 1032. 
loss recognized by $S$ on a subsequent taxable sale or exchange equals the fair market value of the assets or stock received from $T$ minus the fair market value of the $P$ stock as measured at the moment that $S$ received it. The subsidiary thus recognizes the gain or loss that accrued during the period for which it held the parent's stock. If the second step of the triangular transaction-the transfer of the $P$ shares to $T$-follows immediately on the first, there is no gain or loss. Under the quasitreasury stock approach, the same tax result would obtain irrespective of the duration for which $S$ held the $P$ stock. $S$ 's basis in the $P$ stock would be the fair market value of the shares at the time of the transfer to $T$, even if the $P$ stock had been received by $S$ much earlier. In an arm's length transaction, the fair market values of the $T$ stock or assets and the $P$ stock are likely to be equivalent, and the amount of gain or loss would be zero. ${ }^{122}$ Under the quasi-treasury stock approach, therefore, the nonqualifying triangular transaction has substantially the same tax consequences for $S$ and $P$ as a successful "stock-for-stock" or "stockfor-assets" reorganization ${ }^{123}$-no recognition of gain or loss by $P$ and $S$, and a carryover basis for the $T$ stock or assets received. This similarity in tax consequences has both advantages and disadvantages. ${ }^{124}$

The quasi-treasury stock characterization treats the wholly-owned subsidiary and its parent as if they were one combined corporation..$^{125}$ The parent has virtually the same control over its shares in the subsidiary's hands as in its own treasury. ${ }^{126}$ The triangular transaction

122 It is possible, however, to have an exchange of two properties of unequal value even in an arm's length transaction. See Greenbaum, supra note 88, at 370.

123 INT. REv. Code § 368(a)(1)(B), (a)(1)(C).

124 See text and notes at notes $129,134-35$ infra.

125 In a nontax context, it has been recognized that, "with respect to a proposed sale by a subsidiary of securities of its parent company. . . . [i]f form is not permitted to obscure substance, the subsidiary and the parent must be deemed to be the same entity. . . " SEC Securities Act Release No. 4818 (Jan. 21, 1966).

126 It is the opinion of the Committee on Corporate Taxation, supra note 8, at 150, that a parent rarely issues shares of its stock to its subsidiary in the absence of a plan contemplating the subsidiary's transfer of such stock to a third party. The requirement that $P$ corporation's stock must be "fully paid and non-assessable," e.g., Ill. Rev. Stat., ch. 32, § 157.18 (1971); ABA-ALI Model Bus. Corp. Acr \& 19 (2d ed. 1971), may not be met in the absence of such a plan or receipt of other consideration. It is questionable whether the absence of a plan in a triangular reorganization would ever occur when $P$ holds all of S's stock. Freling, Current Problems in Subsidiary Mergers and Other Triangular Reorganizations, supra note 8 , at 386 , observes that a subsidiary would rarely undertake an acquisition in exchange for its parent's stock without express authority. Furthermore, $S$ is frequently formed solely for the purpose of executing a triangular acquisition. Also, the target corporation may require warranties of $S$ 's performance from $P$, since the latter has total control of its subsidiary. On the other hand, if tax consequences in certain situations favor the making of triangular acquisitions in the absence of such a plan, it is foreseeable that, when the stock is transferred to $S$, any appearance of a plan of triangular reorganization will be carefully avoided. 
would have the same result for $P$ and $S$ as a disposition by $P$ of treasury stock after holding the shares for a period during which the value of the stock changed. Gain or loss would be recognized to $T$, however, to the same extent as under the cost or fair market value approach.

Technically, the transfer of $P$ stock from $S$ to $T$ would still be a recognition event; ${ }^{127}$ but the amount of gain or loss recognized would be zero. This approach differs from what might be termed a pure treasury stock approach, under which $S$ would enjoy the nonrecognition protection that is accorded to $P$ when $P$ itself executes the exchange with $T$-thus eliminating altogether the formal separation of $S$ and $P .{ }^{128}$

\section{B. Advantages of the Quasi-Treasury Stock Variant}

The most obvious benefit of this variant of the fair market value method is uniformity of tax result from patterns and routes of transfer that differ only formalistically. Under the quasi-treasury stock approach, no gain or loss is recognized by a subsidiary on disposition of its parent's stock irrespective of (1) the identity of the transferor of the parent's stock to the subsidiary (the parent, a known but unrelated third party, or an open market seller); (2) prior history of the stock if acquired from the parent (newly issued or treasury shares); and (3) the type of transfer from the parent to the subsidiary (as a contribution to capital, in exchange for cash, or in exchange for stock of the subsidiary). ${ }^{129}$ The quasi-treasury stock approach also would prevent the subsidiary from recognizing a capital loss that could be artificially created under the cost or fair market value approach. Assume that $P$ has transferred shares of its no-par stock to $S$ in a tax-free exchange. Later $P$ issues an equivalent amount of shares of the same class of stock-at a price substantially below fair market value-so that the number of shares outstanding is doubled..$^{130} S$, however, does not participate in this new offering ${ }^{131}$ and therefore holds proportionately fewer shares of $P$ stock. If $S$ had exchanged the $P$ shares to $T$ immediately before the new issue of stock, it would have received in return an agreed upon amount

127 INT. REv. CoDE $\$ \S 1002,1001$.

128 Nonrecognition and recognition of zero gain or loss have, for all practical purposes, identical effects on $S$.

129 Committee on Corporate Taxation, supra note 8, at 154-55.

130 There may be a valid business reason for this maneuver. If $P$ needs cash, selling the new issue below the fair market value that prevailed just before the sale might be a rational strategy.

$131 S$ would probably be precluded from participation in the new issue because of corporate law prohibitions against granting pre-emptive rights to a subsidiary in its parent's stock. Even if such rights were granted, $S$ probably would not have the funds to make such a purchase, and $P$ assumedly would lack the liquidity to contribute the funds prior to the distribution of the new issue of $P$ stock. 
of $T$ stock or assets with a fair market value of $\$ X$. Immediately after the new issue, the shares held by $S$ are worth significantly less. ${ }^{132}$ Accordingly, $T$ will now offer some lesser value in stock or assets. $S$ 's basis in the $P$ stock would be fixed at its fair market value at the time of issuance from $P$ to $S$, and a taxable exchange with $T$ immediately after the issuance of new shares would yield a loss under section $1001 .{ }^{133}$ If the quasi-treasury stock variant were adopted, however, $S$ 's basis in the $P$ stock would be measured by the fair market value at the moment of exchange between $S$ and $T$; $T$ 's stock or assets would be of equivalent value and the result to $S$ would be a taxable exchange, but the amount of gain or loss recognized would be zero.

\section{Disadvantages of the Quasi-Treasury Stock Variant}

The most troublesome feature of the quasi-treasury stock approach is the elimination of tax on the appreciation of the parent's stock between the time of its transfer to the subsidiary and the time of the transaction with the target corporation. ${ }^{134}$ This loss of revenue would occur, however, only when that interval was substantial and the $P$ stock had appreciated in value, and never when the subsidiary was created contemporaneously with the acquisition. Moreover, it is not at all clear that this loss of revenue exceeds the amount of tax eliminated by artificial capital losses under the present scheme. Where a postponement of recognition is desired, the quasi-treasury stock approach does not destroy the incentive for $P$ and $T$ to conform their transaction to the requirements for reorganizations, because where $T$ holds appreciated assets it still faces immediate recognition if the transaction does not qualify. ${ }^{135}$

Adoption of the quasi-treasury stock approach might also cause problems of valuation. Because the basis of the $P$ stock held by $S$ is undetermined, $P$ 's basis in the $S$ stock it holds is also undetermined. Problems of valuation would arise if the parent sold all or part of the subsidiary's stock before the subsidiary disposed of the previously transferred $P$ stock. The solution to this problem is to increase P's basis in its $S$ stock by an amount equal to the fair market value of the $P$ shares at the time of their transfer to $S$. The postponement of the

132 Because the number of outstanding $P$ shares has doubled, the value of each $P$ share held by $S$ is now equal to one-half of its former value plus the pro rata amount of the proceeds received by $P$ on this new issue.

133 This transaction may be recast, however, to eliminate recognition of the loss. See text and note at note 91 supra.

134 See Rev. Rul. 70-305, 1970-1 Cum. Bull. 169.

135 INT. REv. CODE § 1002. 
determination of $S$ s basis in the $P$ shares is an exception to ordinary basis principles, and is acceptable only because the other methods cause difficulties and inconsistencies in treatment of triangular acquisitions. There is no reason to broaden this exception to embrace determination of $P$ 's basis in $S$, which can be determined adequately under the cost or fair market value method.

\section{Amending the Code}

The quasi-treasury stock variation is inconsistent with current basis, rules under the Code. $S$ 's basis in the $P$ stock, under the quasi-treasury stock approach, would be the fair market value of the $P$ shares at the time of a subsequent taxable distribution. The Code presently provides for determination of the basis of the $P$ stock to $S$ as computed at the time of the transfer from $P$ to $S .136$

The quasi-treasury stock approach is also inconsistent with several recent revenue rulings. In one case ${ }^{137}$ a wholly-owned subsidiary purchased shares of its parent's stock on the open market and later sold the stock to outside interests at a gain. Under the quasi-treasury stock analysis, the gain or loss recognized by the subsidiary on the transaction would be zero. The Service refused to make such a finding and held instead that: "[T]he stock of $P$ held by $S$ is not treasury stock and the sale of such stock is not to be treated as a sale by the corporation of its own capital stock pursuant to the provisions of section 1032 of the Internal Revenue Code of 1954. The sale of such stock to outside interests is a transaction resulting in a gain or loss." 138

This ruling indicates that the parent's shares held by the subsidiary are not to be considered treasury stock for purposes of section 1032. This decision is consistent with the attitude that the subsidiary's shares are not treasury stock of the parent, and therefore gain or loss must be recognized on a taxable disposition of the parent's "investment" in the subsidiary. As an investment, the basis of the subsidiary's shares to the parent could not be properly determined according to the quasitreasury stock approach.

More recently the Service has stated that the $P$ stock received by $S$ constitutes "voting stock" as used in the definition of a (B) reorganization under section $368(\mathrm{a})(1)(\mathrm{B})$, "regardless of whether, by virtue of state law, it may be voted in the hands of $S$. ."139 Inability to vote the $P$

138 Although the Code does not explicitly state the time at which basis is to be computed, determination of basis at the time of acquisition is a logical implication of the cost basis concept. See INT. REv. CODE §§ 1002, 1011, 1012.

137 Rev. Rul. 70-305, 1970-1 Cum. BuL.. 169.

138 Id.

139 Rev. Rul. 73-28, 1973 INT. REv. BuLx. No. 3, at 6. 
stock is one of the major reasons for treating that stock in the hands of $S$ as quasi-treasury stock of $P .{ }^{140}$ The ruling thus indicates that, at least for purposes of section 368 reorganizations, the corporate law attributes $^{141}$ that form the justification of the quasi-treasury stock variation will be ignored. In the hypothetical case described in the ruling the parent corporation had transferred some of its own voting stock to its wholly-owned, first-tier subsidiary in exchange for all of the stock of a corporation wholly owned by the first-tier subsidiary. The Service analyzed this exchange as a reorganization under section $368(a)(1)(B)$. Although the fact situation could have been used to introduce quasitreasury stock analysis under section 1032-because only a parent and first- and second-tier wholly-owned subsidiaries were involved-the transaction was not so analyzed.

\section{ConCLUSION}

Triangular acquisitions raise problems not foreseen by the drafters of the Internal Revenue Code of 1954. The zero basis theory reads sections 118 and 1032, which had no pre-1954 counterparts, as technically applicable to triangular acquisitions, although their legislative histories and corresponding Treasury regulations do not even hint of such an application. Section 351, which apparently was designed to preclude recognition upon incorporation, is also stretched considerably to apply to acquisitions that do not qualify as reorganizations. If these sections are applicable, the same carryover basis provision-section 362 - that governs acquisitions that qualify as reorganizations must be made to apply to nonqualifying transactions. Finally, under the zero basis theory the term "cost", as ambiguously used in the general definition of basis in section 1012, is given a highly artificial meaning.

The zero basis method for determining the bases of parent and subsidiary corporations in each other's stock is a brittle and needlessly metaphysical interpretation of the provisions of the Internal Revenue Code. The cost or fair market value alternative provides an escape from the semantic abstractions of the zero basis theory without requiring amendments to the Code. It reduces the effect of form and routing on the tax results of corporate acquisitions, yet preserves the Code's limitations on postponement of recognition of gain or loss. The quasitreasury stock approach, although not reconcilable with the present

140 Committee on Corporate Taxation, supra note 8, at 154.

141 Cf. Italo Petroleum Corp. v. Producers Oil Corp., 20 Del. Ch. 283, 174 A. 276 (Ch. 1934); Cummings v. United Artists Theatre Circuit, Inc., 237 Md. 1, 13, 204 A.2d 795, 801 (1964); Ill. Rev. Stat., ch. 32, \& 157.28 (1971); ABA-ALI MODEL Bus. CoRP. ACr § 33 (2d ed. 1971). 
Code provisions, would even more effectively reduce the impact of formal differences among economically indistinguishable corporate acquisitions. Perhaps most significant, both of these latter alternatives would eliminate taxation of a gain that is in no sense a product of economic appreciation in the value of property. The zero basis interpretation should be abandoned in order to focus tax policy on the economic significance of triangular acquisitions, instead of on the way the pieces of paper change hands.

Sheldon I. Banoff 